\title{
Inelastic Analysis of Two Plates Under Deformation Dependent Loads
}
S. K. Iskander
C. W. Collins
J.P. Sanders 


\section{DISCLAIMER}

This report was prepared as an account of work sponsored by an agency of the United States Government. Neither the United States Government nor any agency Thereof, nor any of their employees, makes any warranty, express or implied, or assumes any legal liability or responsibility for the accuracy, completeness, or usefulness of any information, apparatus, product, or process disclosed, or represents that its use would not infringe privately owned rights. Reference herein to any specific commercial product, process, or service by trade name, trademark, manufacturer, or otherwise does not necessarily constitute or imply its endorsement, recommendation, or favoring by the United States Government or any agency thereof. The views and opinions of authors expressed herein do not necessarily state or reflect those of the United States Government or any agency thereof. 


\section{DISCLAIMER}

Portions of this document may be illegible in electronic image products. Images are produced from the best available original document. 


\section{Printed in the United States of America. Available from National Technical Information Service \\ U.S. Department of Commerce \\ 5285 Port Royal Road, Springfield, Virginia 22161}

Price: Printed Copy $\$ 5.00$; Microfiche $\$ 2.25$

This report was prepared as an account of work sponsored by the United States Government. Neither the United States nor the Energy Research and Development Administration, nor any of their employees, nor any of their contractors, subcontractors, or their employees, makes any warranty, express or implied, or assumes any legal liability or responsibility for the accuracy, completeness or usefulness of any information, apparatus, product or process disclosed, or represents that its use would not infringe privately owned rights. 
ORNL/TM-5206

Contract No. W-7405-eng-26

Reactor Division

INELASTIC ANALYSIS OF TWO PLATES UNDER DEFORMATION DEPEIDENT LOADS

S. K. Iskander* C. W. Collins ${ }^{\dagger}$

J. P. Sanders

FEBRUARY 1976

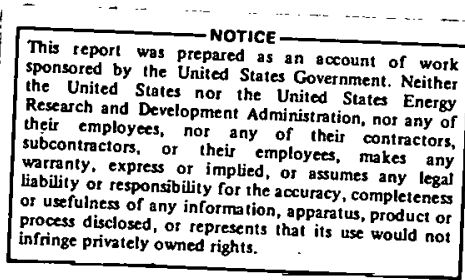

Work performed for the U.S. Nuclear Regulatory Commission under Interagency Agreement 40-494-75.

NOTICE: This document contains information of a preliminary nature and was prepared primarily for internal use at the oak Ridge National Laboratory. It is subject to revision or correction and therefore does not represent a final report.

OAK RIDGE NATIONAL LABORATORY

Oak Ridge, Tennessee 37830

operated by

UNION CARBIDE CORPORATION

for the

U.S. ENERGY RESEARCH AND DEVELOPMENT ADMINISTRATION

* Member of the Computer Science Division, UCCND. tMember of the Engineering Division, UCCND. 


\section{THIS PAGE}

\section{WAS INTENTIONALLY \\ LEFT BLANK}


CONTENTS

ABSTRACT $\ldots \ldots \ldots \ldots \ldots \ldots \ldots \ldots \ldots \ldots \ldots \ldots \ldots \ldots \ldots \ldots \ldots \ldots \ldots$

INTRODUCTION $\ldots \ldots \ldots \ldots \ldots \ldots \ldots \ldots \ldots \ldots \ldots \ldots \ldots \ldots \ldots \ldots \ldots \ldots$

METHOD OF ANALYSIS $\ldots \ldots \ldots \ldots \ldots \ldots \ldots \ldots \ldots \ldots \ldots \ldots \ldots \ldots$

MATERIAL PROPERTIES $\ldots \ldots \ldots \ldots \ldots \ldots \ldots \ldots \ldots \ldots \ldots \ldots \ldots \ldots \ldots \ldots \ldots$

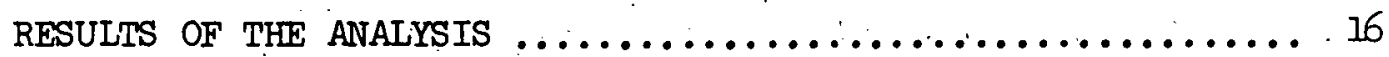

REFERENCES $\ldots \ldots \ldots \ldots \ldots \ldots \ldots \ldots \ldots \ldots \ldots \ldots \ldots \ldots \ldots \ldots \ldots \ldots \ldots$

APPENDIX A. BRIEF DESCRIPTION OF THE EPACA CODE .......... 20 
Fig.

$\underline{\text { Page }}$

1. Square plate showing quadrant analyzed $\ldots \ldots \ldots \ldots \ldots \ldots$

2. Hexagonal plate showing quadrant analyzed $\ldots \ldots \ldots \ldots \ldots \ldots 4$

3. Typical support for the plates analyzed $\ldots \ldots \ldots \ldots \ldots \ldots \ldots$

4. Finite element representation of one quadrant of the square plate showing boundary conditions ........... 8

5. Concept of integrating points and layers in each

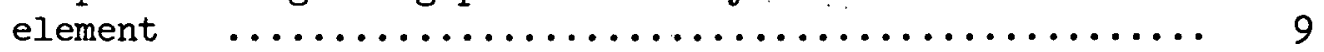

6. Finite element representation of one quadrant of the hexagonal plate showing boundary conditions ........ 10

7. Isochronous stress-strain curves for Hastelloy $X$ at $1800^{\circ} \mathrm{F}-10$ hours used in the finite element analysis... 13

8. Isochronous stress-strain curves for Hastelloy $X$ used in the finite element analysis $\left(2000^{\circ} \mathrm{F}-1\right.$ hour $) \ldots \ldots \ldots . . .14$

9. Average stress-strain curves for $2 \frac{1}{4} \% \mathrm{Cr}-1 \%$ Mo used in the finite element analysis of the hexagonal plate. ...... 15

10. Deflected shape of square plate $\ldots \ldots \ldots \ldots \ldots \ldots \ldots \ldots . \ldots 17$ 


\title{
INELASTIC ANALYSIS OF TWO PLATES UNDER DEFORMATION DEPENDENT LOADS
}

\author{
S. K. Iskander* C. W. Collinst
}

J. P. Sanders

\begin{abstract}
.. . Cover plates are used in current designs for high temperature gas-cooled reactors to compress the mineral fiber insulation against the inside of the liner of the prestressed concrete pressure vessel. In the upper plenum, these plates are hexagonal and specified as carbon steel; in the lower cross ducts, the plates are square and made of Hastelioy $X$. The General Atomic Company has specified both damage and safety limit criteria for. these plates. These plates have been analyzed at these limits using the inelastic finite element computer program EPACA. The results indicate that the total strains for the square plate were within the specified values; however, the maximum deformations at the free corners indicate separation from the insulation and failure to achieve one of the design requirements. Since no material data were available for carbon steel at the limiting temperatures, it was assumed that the hexagonal plates were constructed of $23 \% \mathrm{Cr}-1 \%$ Mo material. Although this material was found to produce satisfactory performance, extrapolation of available information would lead to the conclusion that the performance of carbon. steel plates would not be satisfactory at the specified conditions.
\end{abstract}

Key words: carbon steel, cover plates, deformation, gas coolant, Hastelloy $x$, mechanical properties, reactors, stress analysis, thermal insulation.

\section{INTRODUCTION}

The U.S. Nuclear Regulatory Commission (NRC) has requested the Oak Ridge National Laboratory (ORNL), as part of the studies performed for the Gas-Cooled Reactors Branch (GCRB) of the Division of Reactor Liccnoing (DRL), to assist in the evaluation of the t'irst licensing topical report ${ }^{l}$ for high-temperature gas-cooled reactors (HTGR). As part of this effort, two typical metal cover plates for the insulated liner of the prestressed concrete reactor vessel (PCRV) were analyzed at specified limiting conditions.

* Member of the Computer Science Division, UCCND.

+Member of the Engineering Division, UCCND. 
Current designs for the HTGR at normal operating conditions use high pressure helium with a core inlet temperature of about $600^{\circ} \mathrm{F}$ which is heated to an outlet temperature of about $1400^{\circ} \mathrm{F}$; higher temperatures are reached at upset and faulted conditions. To protect the liner of the PCRV from these temperatures, fibrous insulation is installed between the liner and a metal cover plate which confines the insulation and provides a smooth, clean inner surface that is exposed to the flowing helium. Different amounts of insulation, metal types and shapes, are used throughout the pressure vessel.

Two types of cover plates were selected for analysis as being typical for the entire reactor. The first plate is a 1/4-in. Hastelloy $X$ square plate, shown in Fig. 1, used in the outlet plenum. The second plate is a $1 / 4-i n$. carbon steel hexagonal plate, shown in Fig. 2, used in the inlet plenum. Both plates are supported at the center and at the edges as shown in Figs. 1 and 2. A typical support is shown in Fig. 3. Pressure applied to the plates compresses the 4 in. of Kaowool to 3 in., and the plates are then attached to the supports resulting in an initial maximum preload to the plates of $3 \mathrm{psi}$. The General Atomic Company tested Kaowool to determine the effects of temperature, time, irradiation, and different amounts of precompression. ${ }^{2}$ From these data, it was determined that the initial plate preload would decrease from 3 psi to $0.75 \mathrm{psi}$ due to loss of resiliency at elevated temperature for a relatively short period of time.

The topical report ${ }^{1}$ (GA-LTR-1) gives the design bases for the core cooling systems as determined by subjecting the core and PCRV internals to a set of hypothetical thermal transients to establish the conditions at which component damage could occur. For purposes of evaluating transient severity, two threshold limits for temperatures of important primary system components are defined:

Damage Limit - Defined as that component temperature at which damage may be incurred to the extent that normal plant operation may not be resumed without repairs. "Damage" is defined as the condition when total creep deformation strain exceeds the design limit by $1 \%$. For the square plate, the damage limit was reported as $1800^{\circ} \mathrm{F}$ for $10 \mathrm{hr}$; for the hexagonal plate as $1000^{\circ} \mathrm{F}$ for $10 \mathrm{hr}$. 


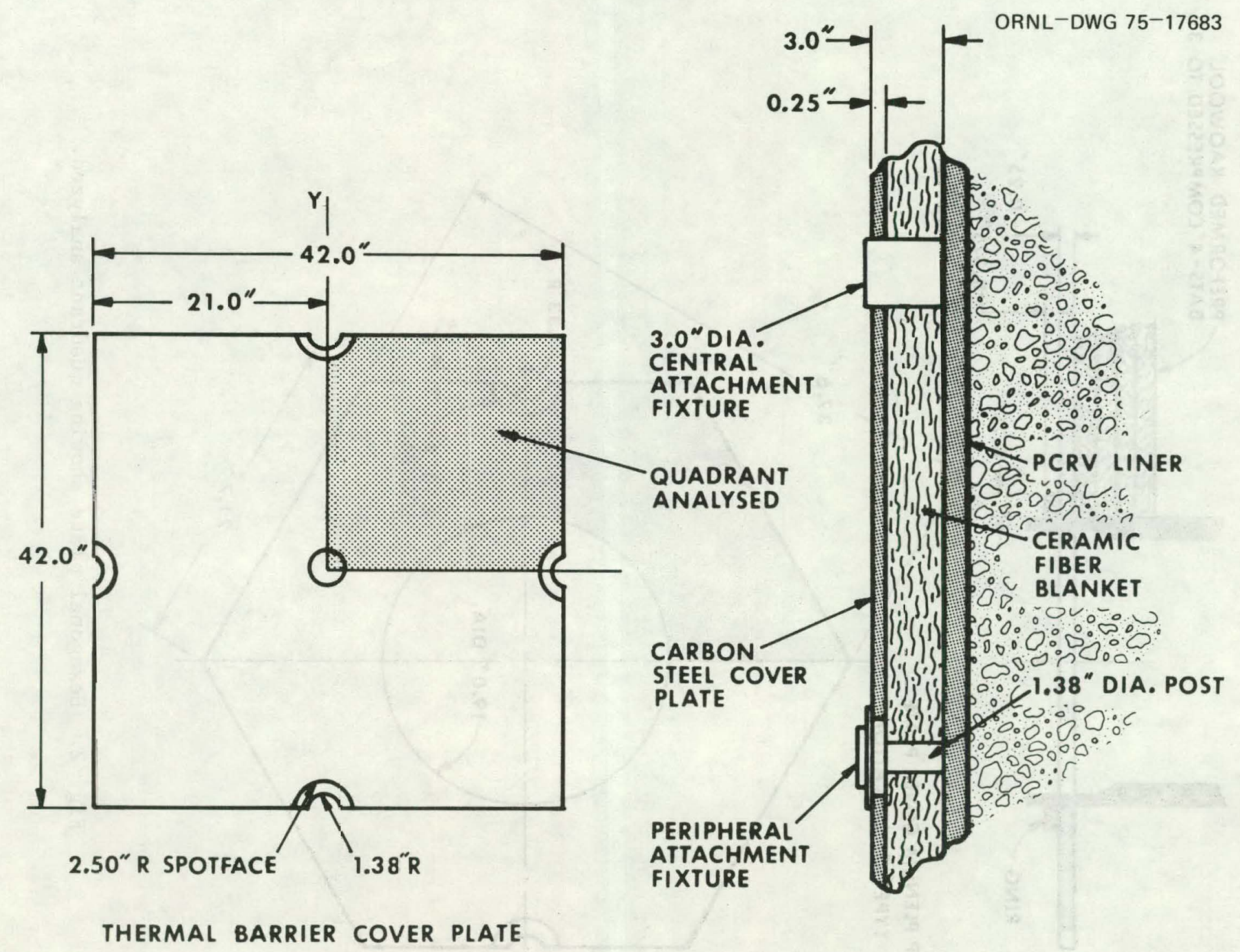

Fig. 1. Square plate showing quadrant analyzed. 


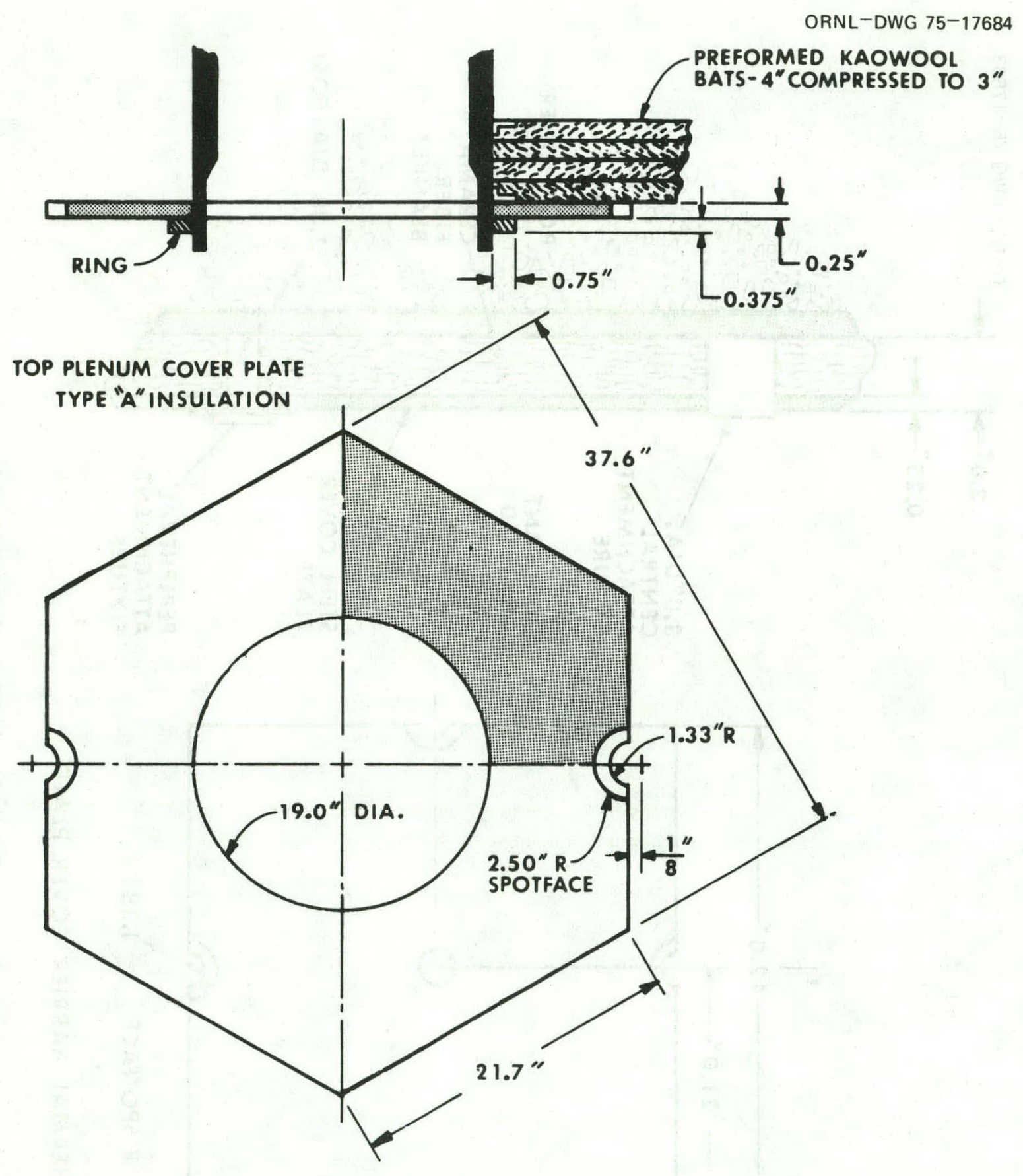

Fig. 2. Hexagonal plate showing quadrant analyzed. 


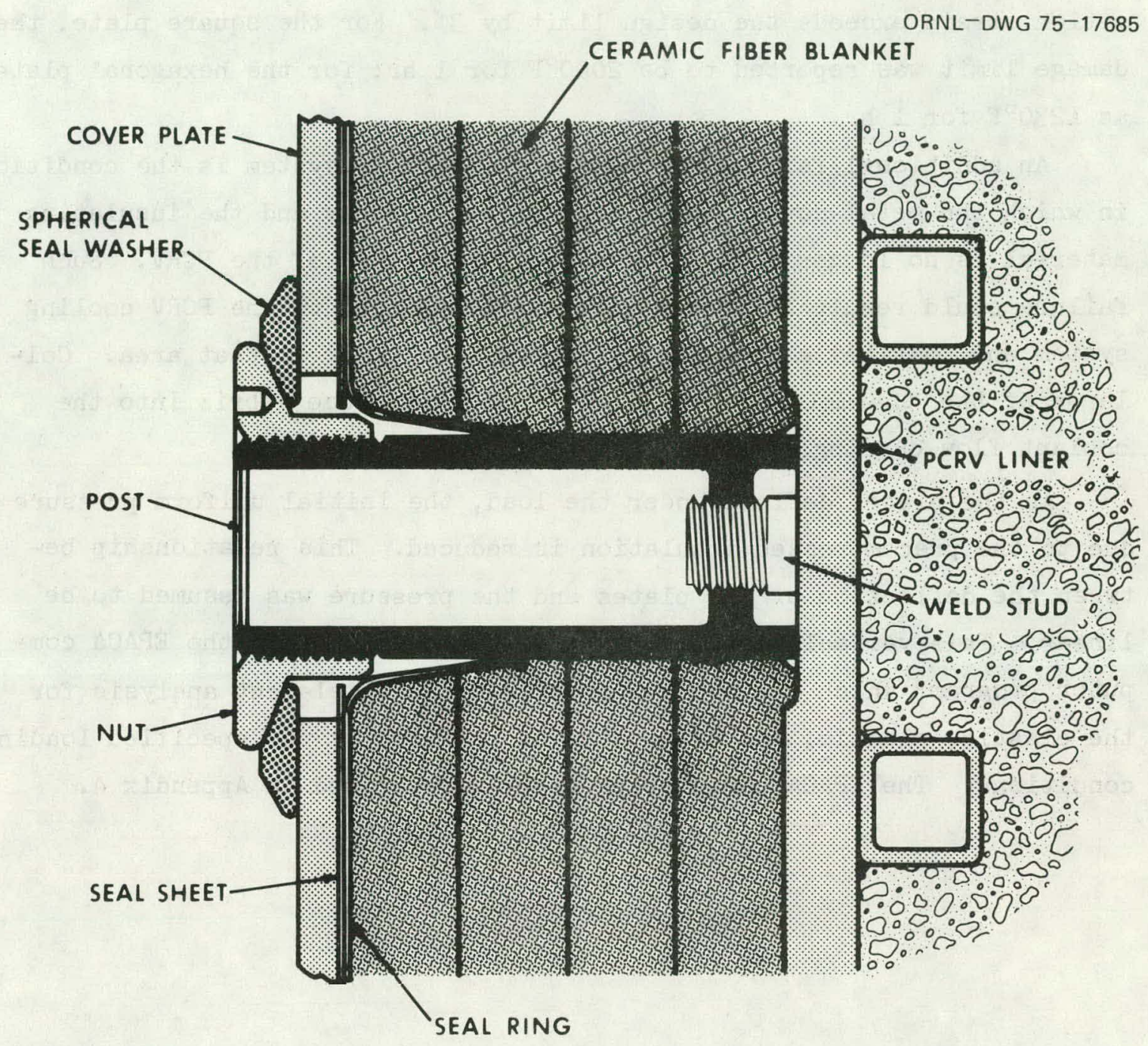

Fig. 3. Typical support for the plates analyzed. 
Critical Safety Limit - Defined as that component temperature at which damage may be incurred to the extent that it would interfere with effective core cooling. Exceeding the "Critical Safety Limit" results in "failure", which is defined as the condition where total creep deformation strain exceeds the design limit by $3 \%$. For the square plate, the damage limit was reported to be $2000^{\circ} \mathrm{F}$ for $\mathrm{l} \mathrm{hr}$; for the hexagonal plate as $1230^{\circ} \mathrm{F}$ for $1 \mathrm{hr}$.

An additional failure of the thermal barrier system is the condition in which the metal cover plates deflect excessively and the insulating material is no longer compressed against the liner of the PCRV. Such failure could result in local excessive heat input to the PCRV cooling system and possibly a buckling failure of the liner in that area. Collapse of the thermal barrier itself could introduce debris into the coolant flow causing blockage of some flow passages.

As the plates deflect under the load, the initial uniform pressure due to the precompressed insulation is reduced. This relationship between the deflection of the plates and the pressure was assumed to be linear. This variable loading was taken into account in the EPACA computer program ${ }^{3}$ which was used to provide a finite element analysis for the elastic, plastic, and creep strains produced by the specified loading conditions. The EPACA computer program is described in Appendix A. 
METHOD OF ANALYSIS

The finite element method necessitates the modeling of the component to be analyzed as an assemblage of elements. In this case, the members to be analyzed were a square plate, Fig. 1, and a hexagonal plate, Fig. 2 . Their symmetrical shapes and loads required only one quadrant to be modeled and analyzed, thereby simplifying the calculations. The outlines of the quadrants are hatched in Figs. 1 and 2 . In both cases, the semicircular recesses were ignored and a straight edged outline was assumed. Although these recesses could lead to stress peaks in the elastic region, these peaks will level off in the plastic region. Also, the washers supporting these plates (see Fig. 3) tend to mitigate any eventual adverse effects of the recesses.

The finite element model of the square plate is shown in Fig. 4. The quadrant of the plate was uniformly subdivided into 49 elements. connected by 64 nodal points. The boundary conditions on two adjacent edges simulated the presence of the remaining parts by restricting the rotations about the $\mathrm{x}$ and $\mathrm{y}$ axes. Furthermore, the plate was simply supported on the three corners of these same edges, leaving one corner free (Fig. 4).

The intemal operation of the code requires the specification of a number of Gaussian integration points in the plane of the plate and parallel to each side of the element. Two such points along each axis were specified. Furthermore, six layers of these points were specified through the thickness for a total of 24 integrating points in each element (see Fig. 5), which is sufficient for accuracy within $\pm 10 \%$. The strains and stresses at these points have a certain amount of freedom to take on the necessary values (see Appendix A).

The hexagonal plate was represented for the finite element analysis as shown in Fig. 6 . In this case, there were 65 nodal points connecting 48 elements. The edges along the $\mathrm{x}$ and $\mathrm{y}$ axes were restricted from rotations, as in the case of the square plate, to simulate the remainder of the plate. Furthermore, the plate was simply supported at the points indicated on Fig. 6. 


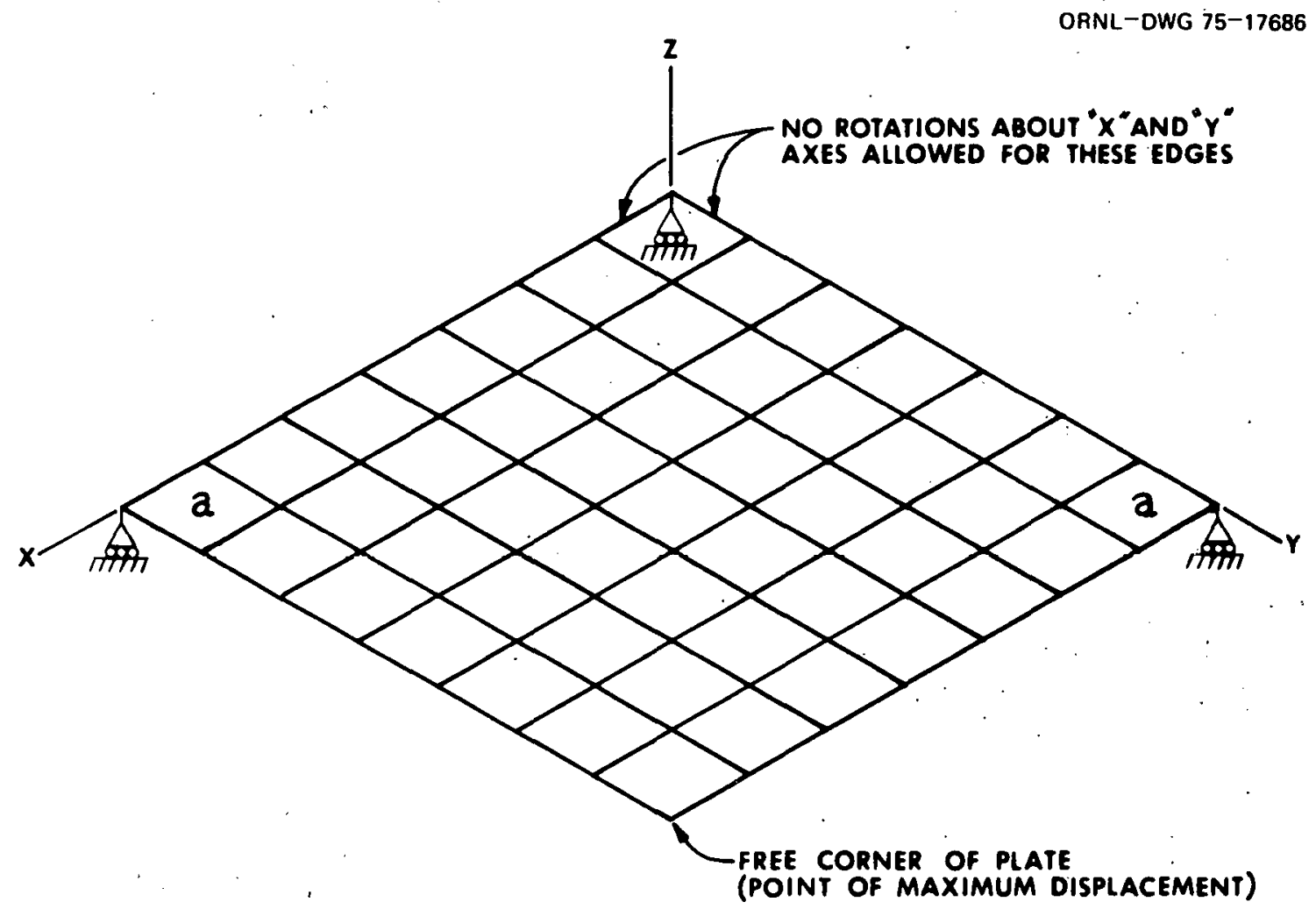

तीIII POINTS OF SIMPLE SUPPORT

Fig. 4. Finite element representation of one quadrant of the square plate showing boundary conditions. 


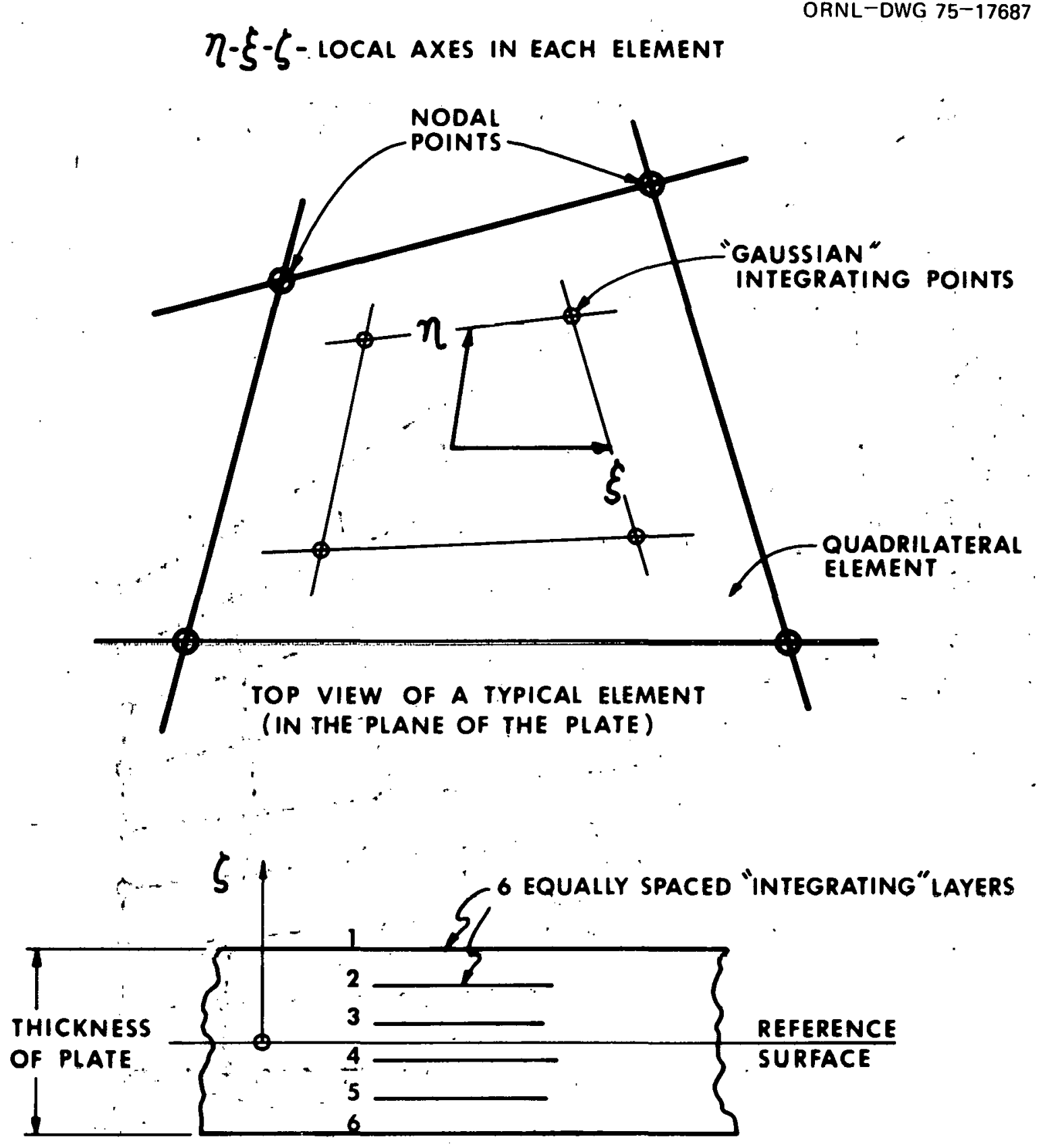

\section{SECTION THROUGH THE THICKNESS OF AN ELEMENT}

Fig. 5. Concept of integrating points and layers in each element. 


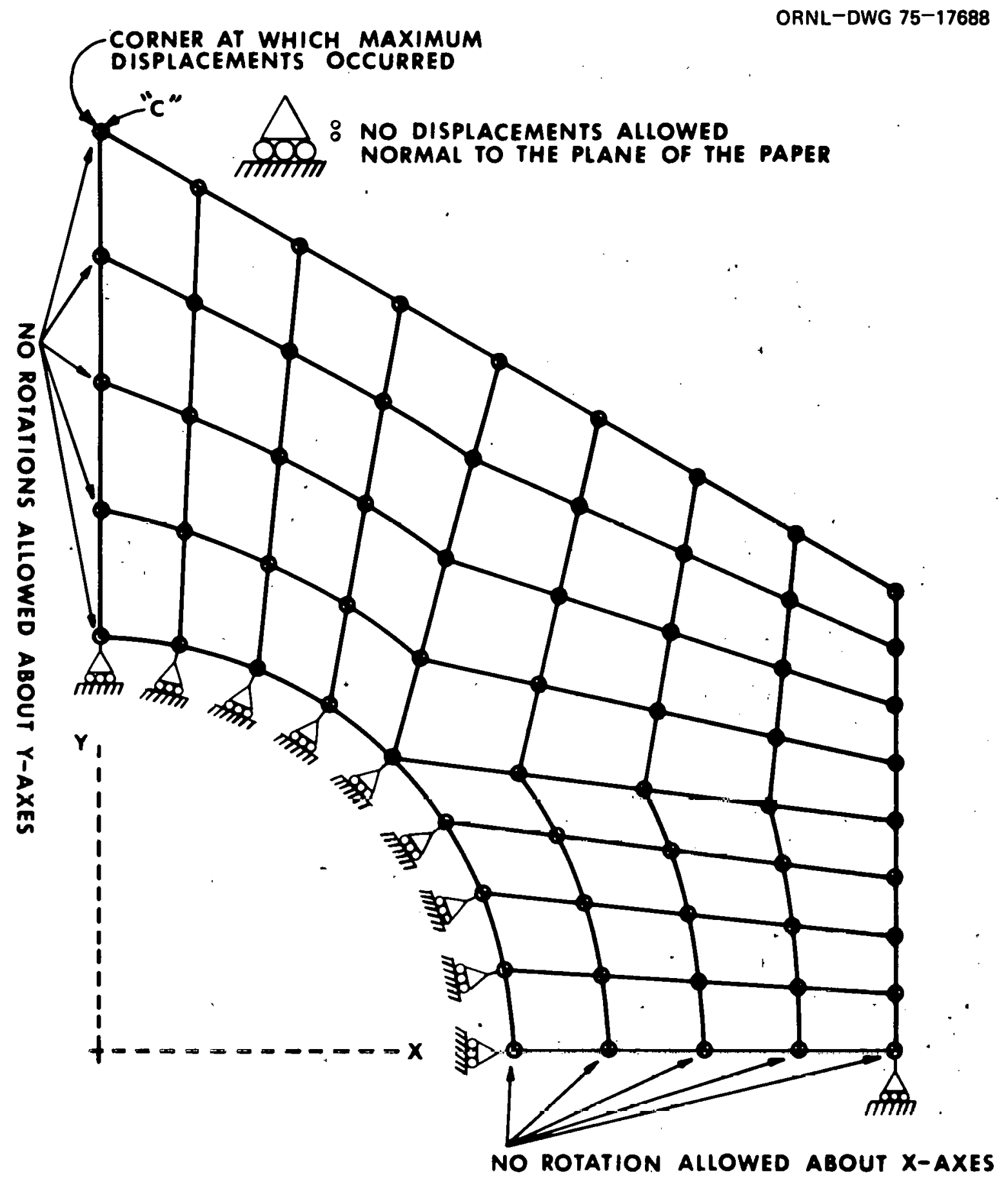

Fig. 6. Finite element representation of one quadrant of the hexagonal plate showing boundary conditions. 
A preliminary analysis showed that the hexagonal plate remained substantially in the elastic region, thus only three integration layers were required through the thickness, although four points were specified in the plane of the plate as in the case of the square plate.

As explained in the appendix, the total load is applied in small increments. The size of these increments started with 0.005 of the full load and.remained at this level for several steps. These were then gradually increased to 0.05 toward the end of the analysis. There were about 25 steps in each of the analyses at $1800^{\circ} \mathrm{F}$ and $2000^{\circ} \mathrm{F}$.

At the end of each increment, the total load for the subsequent steps is reduced at each nodal point by a factor of (1- $\delta$ ), where $\delta$ is the displacement normal to the surface of the plate at the node under consideration: If the displacement exceeded 1 in., no load was applied at that particular node. The l-in. displacement in the above discussion represented the precompression of the Kaowool insulation.

The load on each plate consists mainly of 0.75 psi uniform pressure due to the precompressed insulation. To this was added a relatively small. amount to account for the dead weight of the 0.25-in. plate. 
MATERIAL PROPERTIES

The material properties ${ }^{4}$ used in the analysis of the square plate were for solution treated Hastelloy $X$ and are shown in Figs. 7 and 8 . Figure 7 shows the isochronous stress-strain curves at $1800^{\circ} \mathrm{F}$ in $10 \mathrm{hr}$, while Fig. 8 shows the curves at $2000^{\circ} \mathrm{F}$ for $1 \mathrm{hr}$. The curve labeled as the minimum was used. The initial yield and Youngs Modulus (or the modulus of elasticity) were estimated from these curves. Note the particularly low values of yield, $I$ and $0.5 \mathrm{ksi}$ for $1800^{\circ} \mathrm{F}$ and $2000^{\circ} \mathrm{F}$, respectively, as these are of critical importance in the calculations.

For the hexagonal plate, the material properties were those for $2 \frac{2}{4} \% \mathrm{Cr}-1 \%$ Mo at $1000^{\circ} \mathrm{F}$ for $10 \mathrm{hr}$ and $1200^{\circ} \mathrm{F}$ for $\mathrm{I} \mathrm{hr}$. They can be closely approximated by the so-called bilinear representation and are shown in Fig. 9, taken from ASME code case 1592 (Ref. 5). Note the relatively high yield strengths as compared to the Hastelloy $X$ material. The plastic region of the representation was not utilized in the analysis since the plates remained elastic.

The General Atomic Company had specified the use of carbon steel for the hexagonal plate. However, no data for isochronous stress-strain curves for $1000^{\circ} \mathrm{F}$ and $1200^{\circ} \mathrm{F}$ were available, so the superior high temperature material, $2 \frac{1}{4} \% \mathrm{Cr}-1 \% \mathrm{Mo}$, was substituted because it appeared satisf'actory for the service, and the needed isochronous stress-strain curves were available from ASME code case 1592.

For both plates, the isotropic hardening rule was used in analysis. Since no load reversals occurred, this is of little consequence; however, operation of the code requires the specification of either isotropic or kinematic hardening. 


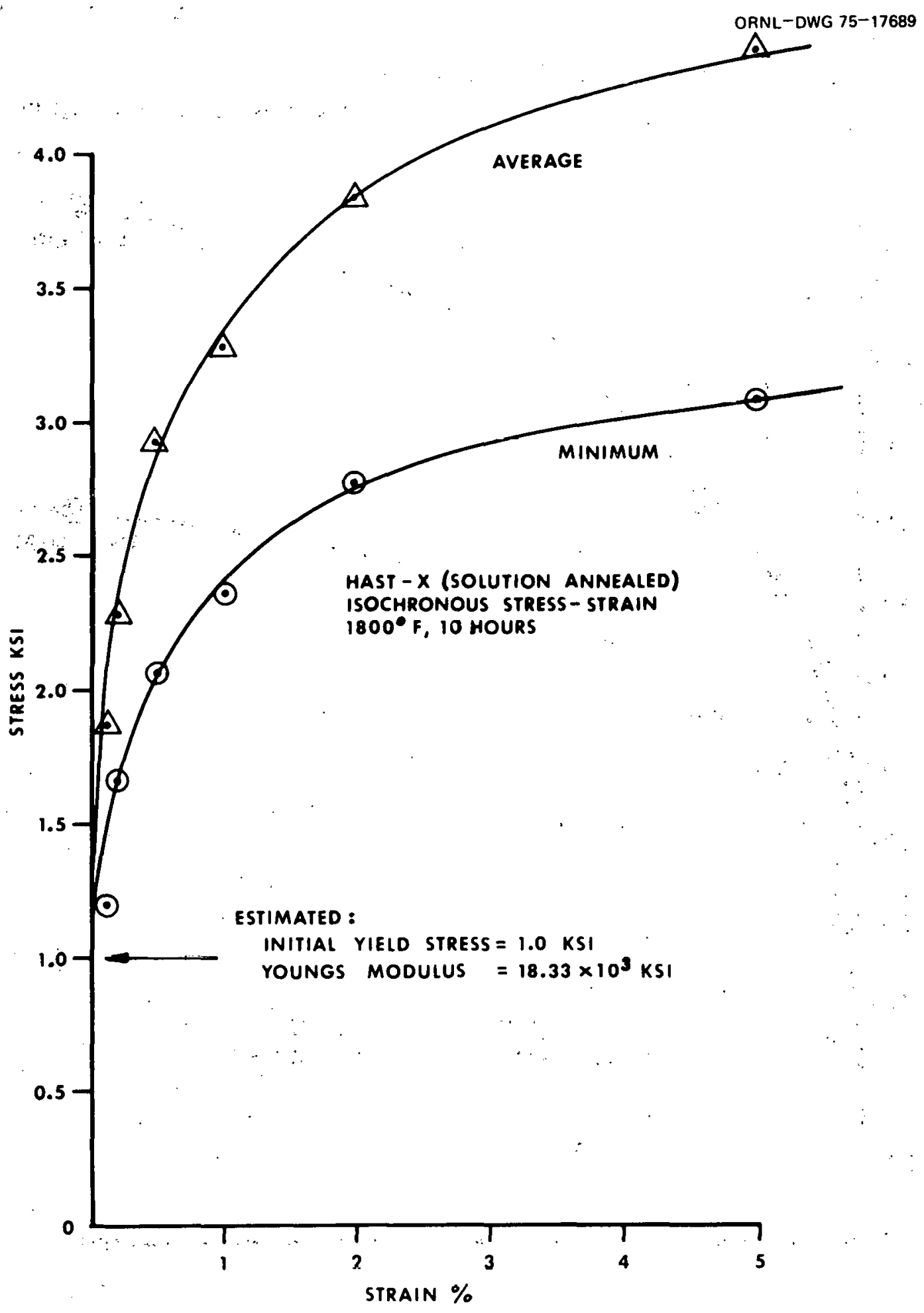

Fig. 7. Isochronous stress-strain curves for HASTELLOY $X$ at $1800^{\circ} \mathrm{F}-$ 10 hours used in the. finite element analysis. 


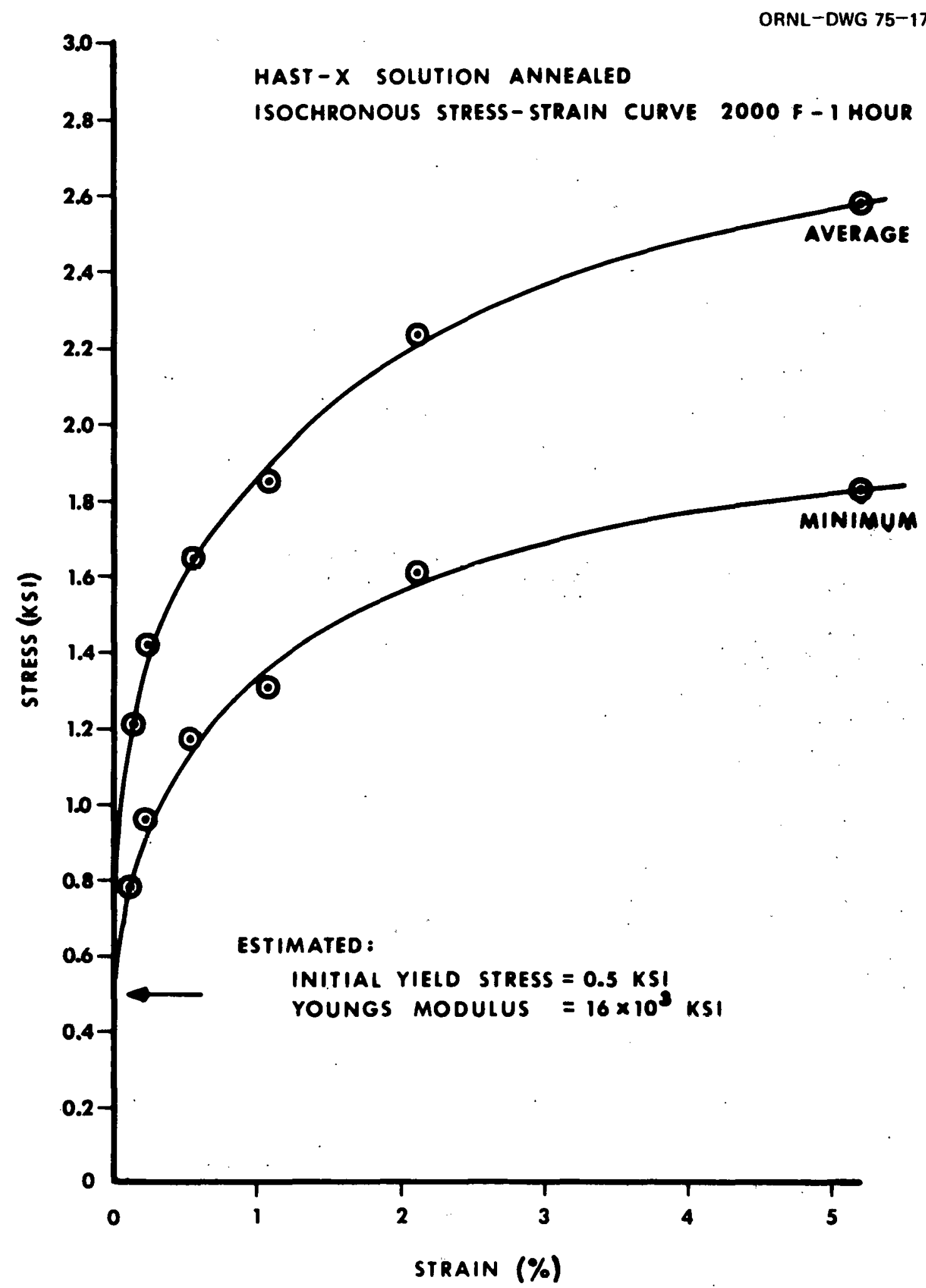

Fig. 8. Isochronous stress-strain curves for HASTELLOY $X$ used in the finite element analysis $\left(2000^{\circ} \mathrm{F}-1\right.$ hour $)$. 


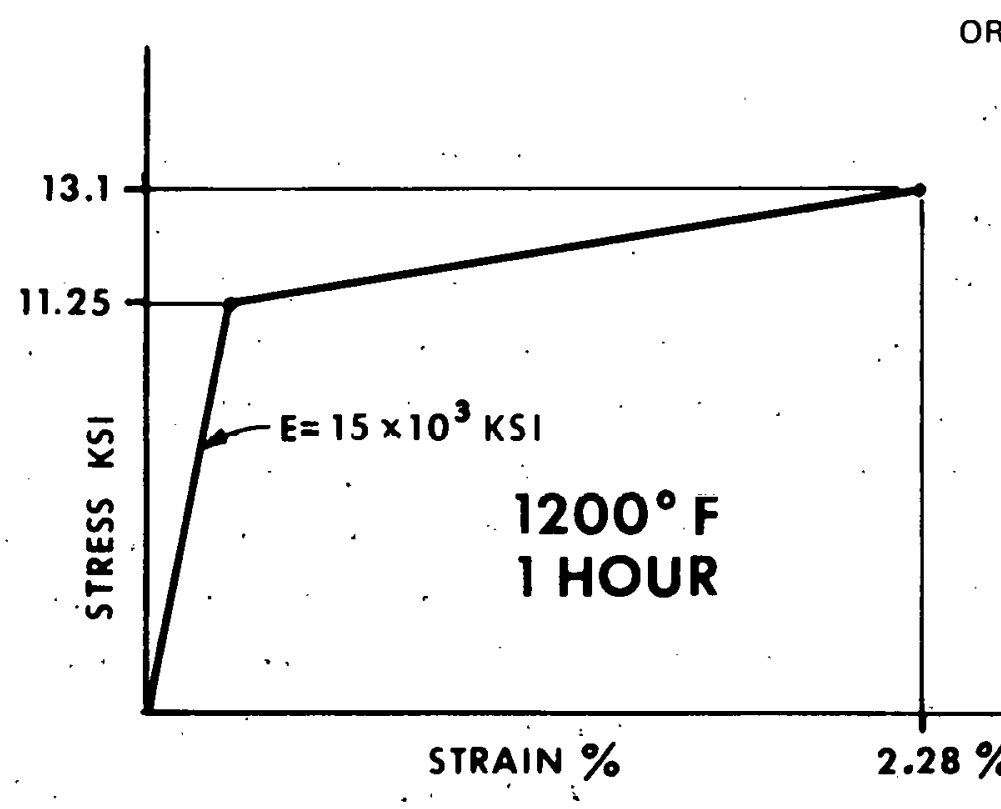

ORNL-DWG 75-17691

(A)

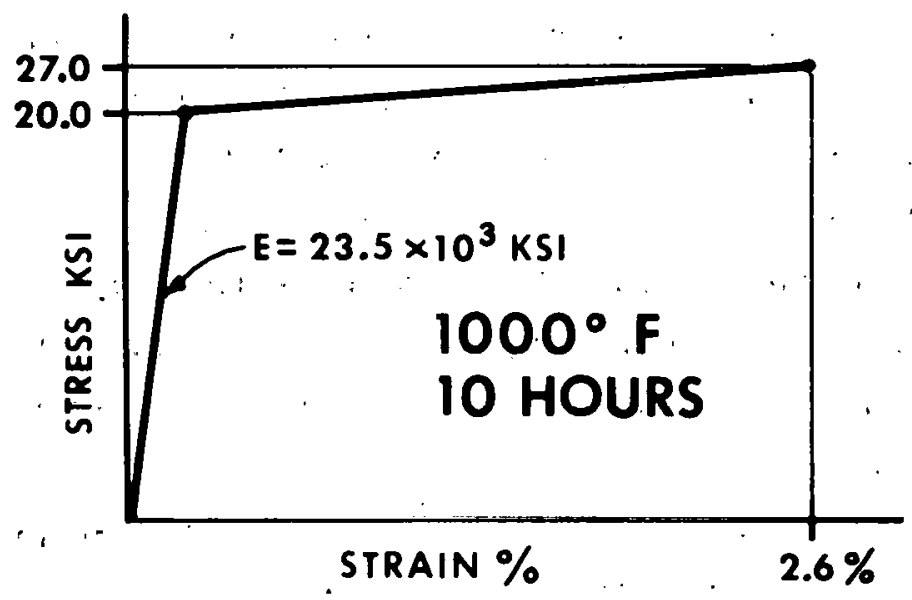

(B)

Fig. 9. Average stress-strain curves for $2 \frac{1}{4} \% \mathrm{Cr}-1 \%$ Mo used in the finite element analysis of the hexagonal plate. Source ASME code case 1592 .

(A) For $1200^{\circ} \mathrm{F}$ and 1 hour; (B) $1000^{\circ} \mathrm{F}$ and 10 hours. 
RESULTS OF THE ANALYSIS

The results of the analysis for the square plate show that the maximum total (elastic, plastic, and creep) strains are $0.35 \%$ and $0.54 \%$ at $1800^{\circ} \mathrm{F}$ and $2000^{\circ} \mathrm{F}$, respectively. These strains occurred close to the midside supports, which would correspond to the elements designated ". $a$ " in the finite element representation, Fig. 4. Moreover, the plates have also undergone extensive inelastic yielding so that they have become permanently warped even under the small loads to which they were subjected. This is due to the very small elastic strength remaining in the plates at these high temperatures. Another manifestation of this is the fact that the free corners of the plate will displace more than 1 in., thus indicating they lift off the insulation, thereby failing to meet one of the design criteria. This occurred for both temperatures, the displacement of the free corner being $1.2 \mathrm{in}$. and $1.63 \mathrm{in}$. $1800^{\circ} \mathrm{F}$ and $2000^{\circ} \mathrm{F}$, respectively. It should be mentioned that these large displacements are beyond the range of "small" displacements for which the usual linear theory of strains apply. However, previous experience with incremental inelastic analysis of structures for which experimental data exist indicates that such analyses reproduce the essential features of the structural response. Exact figures on the accuracy are impossible to obtain. 'They are, however, adequate to indicate a possible problem.

The deformed shape of the quadrant analyzed is shown in Fig. 10. The remaining portions of the square plate deflect in a symmetric manner about the $\mathrm{x}$ and $\mathrm{y}$ axes.

Results for the hexagonal plate did not reveal any such problem. In fact, they indicate that the plate remained substantially elastic and no inelastic strains occurred for the $2 \frac{1}{4} \% \mathrm{Cr}-1 \%$ Mo material substituted for the analysis. The maximum equivalent stresses were of the order of $10 \mathrm{ksi}$, sufficiently below the yield stress of $11.25 \mathrm{ksi}$, at the higher temperature level of $1200^{\circ} \mathrm{F}$ for $1 \mathrm{hr}$ considered.

The maximum deflection of the hexagonal plate was $0.43 \mathrm{in}$. which occurred at cormer C (Fig. 6) and was for the $1200^{\circ} \mathrm{F}$ temperature. 


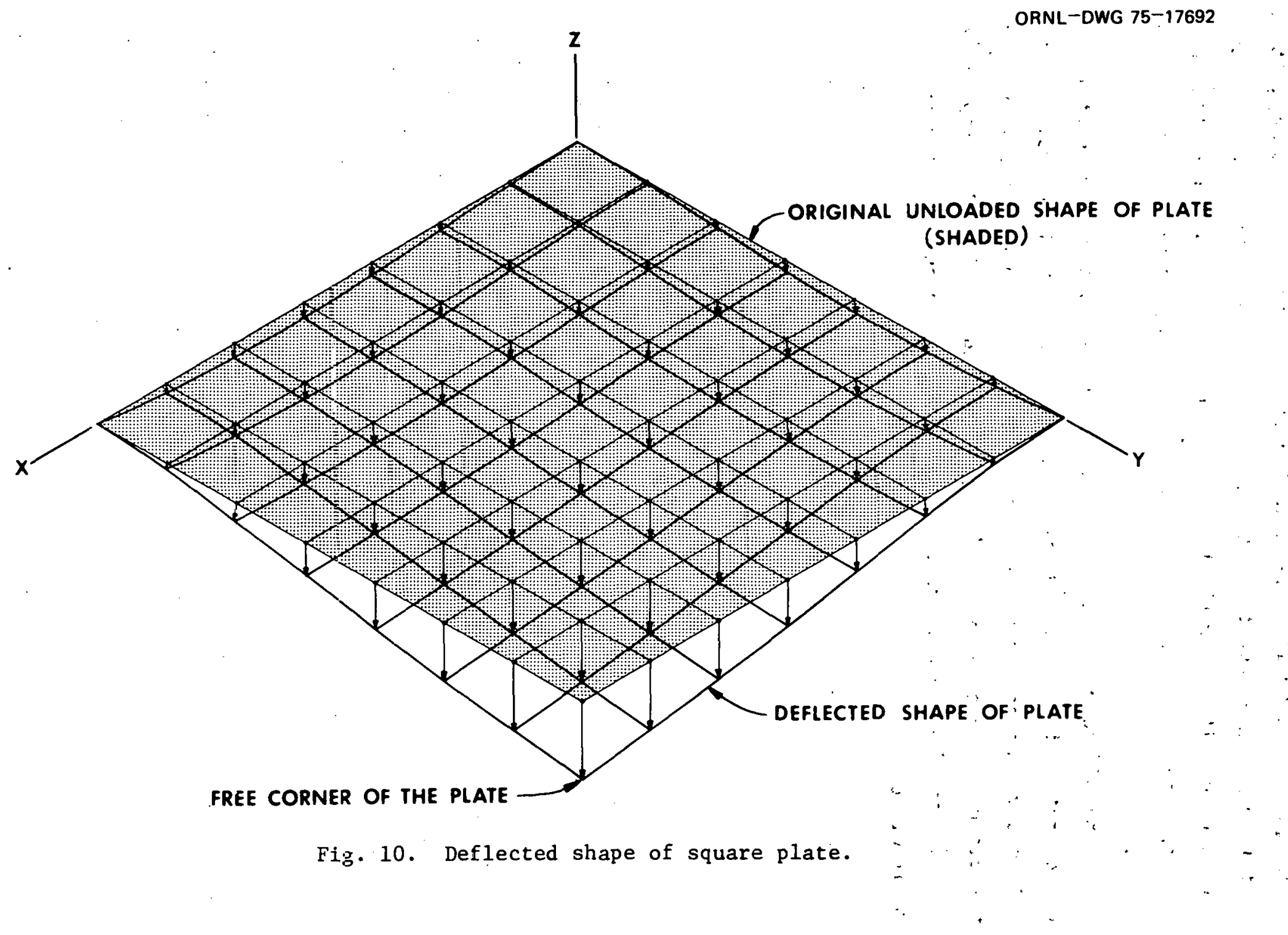


Although the $2 \frac{1}{4} \% \mathrm{Cr}-1 \%$ Mo hexagonal plate was found satisfactory, it must be concluded that the integrity of the carbon steel plates at the specified conditions would be very doubtful since available data show the strength of carbon steel to decrease rapidly at temperatures above. $800^{\circ} \mathrm{F} .6$

Many of the. plate liners for the prestressed concrete reactor are curved rather than flat and are of sizes other than those analyzed in this study. Since the plates are typical, the results indicate most of the plates would satisfy the "Damage Limit" and "Critical Safety Limit" if $2 \frac{3}{4} \% \mathrm{Cr}-1 \%$ Mo material were used instead of carbon steel for the hexagonal plates. 
1. R. W. Schleicher, An Analysis of HTGR Core Cooling Capability, Gulf General Atomic Co., Gulf-GA-Al2504 (GA-LTR-1), (March 1973).

2. Gulf General Atomic, Inc., Compression and Permanent Deformation Characteristics of Fibrous Insulations, GA-P-901-91 (September 1968).

3. W. L. Greenstreet, J. M. Corum, and C. E. Pugh, High-Temperature Structural Design Methods for LMFBR Components Quarterly Progress Report for Period Ending March 31, 1974, ORNL-4977, pp 100-119 . (October 1974).

4. Genera1 Atomic Co., Unpublished Data (March 1974).

5. American Society of Mechanical Engineers, Cases of ASME Boiler and Pressure Vesse1 Code - Case 1592, (April 1974).

6. American Society for Testing and Materials, An Evaluation of the Elevated Temperature Tensile and Creep-Rupture Properties of Wrought Carbon Steel, ASTM Data Series DS 11 S 1 (January 1970). 
APPENDIX A

\section{BRIEF DESCRIPTION OF THE EPACA CODE}

The EPACA code (Elastic-Plastic and Creep Analysis) was originally developed by the Franklin Research Institute for the High Temperature Structural Design Methods program (HTSDM). It has been implemented by the Computer Sciences Division. Part of the implementation consisted of analyzing structures for which experimental results are available and thus verify that the code is operating satisfactorily. This has in fact already been done, and a sample problem shown in the quarterly progress report, ORNL-4977, has been included as an indicator that the code is operating satisfactorily. This shows that the results of computer analysis of plates and beams under loads leading to inelastic strains agree reasonably well with experimental results.

The code is capable of analyzing any structure that can be modeled as an assemblage of flat or curved elements using the finite element method. A system of linear equations relating the unknown generalized displacements to the generalized known forces is formed and solved to yield the displacements from which the strains and stresses can be calculated. The generalized unknown displacements are the three displacements $u, v$, and $w$, and the two rotations $\theta_{x}$ and $\theta_{y}$ at each node. The rotations and displacements are coupled so that an approximation of shell behavior is possible. Thus, stretching of the mid-plane (membrane behavior) and rotations of the normal to this plane (plate behavior) are represented leading to five degrees of freedom at each node. The discrete Kirchoffhypothesis is invoked at the nodes to relate the transverse displacements $w$ to the rotations $\theta_{x}$ and $\theta_{y}$ about axes in the plane of the shell. This permits a close approximation to shell behavior. The transverse shear can also be represented by sultable choice of element type, thus "thick" shells can be analyzed.

Within the plane of the shell or plate, the stresses and strains have a degree of freedom to take arbitrary values at the so-called Gaussian integration points. The number of these points can range 
anywhere between four (two parallel to each of the elements) to sixtyfour $(8 \times 8)$. Furthermore, three to six layers of these integration points could be specified depending upon the degree of "yielding" in these layers. In this analysis, because of the extensive yielding, six layers were specified. There were, therefore, 24 points at which the stresses and strains were calculated; correspondingly, each element had that many "internal degrees of freedom", roughly speaking. Hence, the number of elements or nodal points required for an analys is does not need to be as great as with other codes which employ constant strain elements.

The loads are applied in increments since the theory is formulated in an incremental form. The choice of the size of these increments is still very much a matter of trial and error plus some experience based upon similar analysis. At the end of each step, a test is made at every integration point to determine whether it is on the yield surface (if yielding has occurred at that point). If it deviates from the yield surface by more than a specified tolerance (0.1\%), then controls are set for iterative steps whose purpose it is to bring these points back to the yield surface.

Furthermore, at the end of every incremental or iterative step, the unbalanced loads due to the deviations from equilibrium between the calculated loads, and the actual external loads are corrected in the subsequent steps. 
THIS PAGE

\section{WAS INTENTIONALLY LEFT BLANK}


ORNL/TM-5206

Intermal Distribution

$\begin{array}{cl}\text { 1. } & \text { J. L. Anderson } \\ \text { 2. } & \text { L. L. Anthony } \\ 3 . & \text { S. J. Ball } \\ \text { 4. } & \text { B. Beard } \\ 5 . & \text { H. C. Beeson } \\ 6 \text {-7.. } & \text { A. A. Brooks } \\ 8 . & \text { J. P. Callahan } \\ 9 . & \text { D. A. Canonico } \\ \text { 10. } & \text { H. P. Carter } \\ 11 . & \text { J. C. Cleveland } \\ 12 . & \text { J. A. Clinard } \\ 13 . & \text { T. E. Cole } \\ 14-18 . & \text { C. W. Collins } \\ 19 . & \text { D. Constanzo } \\ 20 . & \text { J. H. Coobs } \\ 21 . & \text { J. M. Corum } \\ 22 . & \text { W. B. Cottrell } \\ 23 . & \text { F. L. Culler } \\ 24 . & \text { R. M. DeVault } \\ 25 . & \text { G. G. Fee } \\ 26 . & \text { M. H. Fontana } \\ 27 . & \text { Uri Gat } \\ 28 . & \text { G. E. Giles, Jr. } \\ 29 . & \text { M. J. Goglia } \\ 30 . & \text { R. W. Henderson } \\ 31 . & \text { H. W. Hoffman } \\ 32 . & \text { F. J. Homan } \\ 33 \text { 42. S. K. Iskander } \\ 43 . & \text { J. D. Jenkins } \\ 44 \text { 46. } & \text { P. R. Kasten } \\ & \end{array}$

47. A. L. Lotts

48. R. E. MacPherson/

J. A. Conlin

49. A. P. Malinauskas

50. R. D. McCulloch

51. Walter J. McCarthy

52. D. D. Paul

53. C. E. Price

54. H. Postma

55. P. L, Rittenhouse

56. M. W. Rosenthal

57-71. J. P. Sanders

72. Dunlap scott

73. Myrtleen Sheldon

74. I. Spiewak

75. J. R. Tallackson

76. John J. Taylor

77. R. E. Textor

78. D. B. Trauger

79. W. D. Turner

80. G. W. Westley

81. G. E. Whitesides

82. G. D. Whitman

83. W. J. Wilcox

84. L. N. Wilson

85. ORNL Patent Office

86 -87. Central Research Library

88. Document Reference Section

89-93. Laboratory Records Department

94. Laboratory Records Department(RC)

\section{Extermal Distribution}

95. Director, Division of Reactor Licensing, USNRC, Washington, D.C. 20555

96. Director, Division of Technical Review, USNRC, Washington, D.C. 20555

97-106. Assistant Director for Reactor Safety, Division of Technical Review, USNRC, Washington, D.C. 20555

107-117. Chief, Gas Cooled Reactors Branch, Division of Reactor Licensing, USNRC, Washington, D.C. 20555

118. Chief, Reactor Systems Branch, Division of Technical Review, USNRC, Washington, D.C. 20555

119. Chief, Core Performance Branch, Division of Technical Review, USNRC, Washington, D.C. 20555 
120-121. Director, Office of Nuclear Regulatory Research, USNRC, Washington, D.C. 20555

122. Assistant Director, Advanced Reactor Safety Research, Division of Reactor Safety Research, USNRC, Washington, D.C. 20555

123. Chief, Experimental Gas Cooled Reactor Safety Research Branch, Division of Reactor Safety Research, USNRC, Washington, D.C. 20555

124. Director, Division of Reactor Research and Development, ERDA, Washington, D.C. 20545

125-127. Office of Reactor Safety Research Coordination, ERDA, Washington, D.C. 20545

128. Assistant Director, Gas Cooled Reactor Projects, Division of Reactor Research and Development, ERDA, Washington, D.C. 20545

129. Assistant Director, Reactor Safety, Division of Reactor Research and Development, ERDA, Washington, D.C. 20545

130. Chief, Gas Reactor Safety Branch, Division of Reactor Research and Development, ERDA, Washington, D.C. 20545

131. Director, Research and Technical Support Division, ERDA, ORO

132. Director, Reactor Division, ERDA, ORO

133-159. Technical Information Center, ERDA, ORO

150. W. H. Beach, EGCRSRB, Division of Reactor Safety Research, USNRC, Washington, D.C. 20555

161. A. Bournia, Gas Cooled Reactors Branch, Division of Reactor Licensing, USNRC, Washington, D.C. 20555

162. R. E. Ireland, Division of Technical Review, USNRC, Washington, D.C. 20555

163. E. Lantz, Gas Cooled Reactors Branch, Division of Reactor Licensing, USNRC, Washington, D.C. 20555

164. R. Lobel, Division of Technical Review, USNRC, Washington, D.C. 20555 